Mark E. Brandriss $\cdot$ Richard J. Nevle $\cdot$ Dennis

K. Bird · James R. O'Neil

\title{
Imprint of meteoric water on the stable isotope compositions of igneous and secondary minerals, Kap Edvard Holm Complex, East Greenland
}

Received: 22 March 1994 / Accepted: 26 January 1995

\begin{abstract}
Hydrogen and oxygen isotope analyses have been made of hydrous minerals in gabbros and basaltic xenoliths from the Eocene Kap Edvard Holm intrusive complex of East Greenland. The analyzed samples are of three types: (1) primary igneous hornblendes and phlogopites that crystallized from partial melts of hydrothermally altered basaltic xenoliths, (2) primary igneous hornblendes that formed during late-magmatic recrystallization of layered gabbroic cumulates, and (3) secondary actinolite, epidote and chlorite that formed during subsolidus alteration of both xenoliths and gabbros. Secondary actinolite has a $\delta^{18} \mathrm{O}$ value of $-5.8 \%$ and a $\delta \mathrm{D}$ value of $-158 \%$. These low values reflect subsolidus alteration by low- $-\delta^{18} \mathrm{O}$, low- $\delta \mathrm{D}$ hydrothermal fluids of meteoric origin. The $\delta \mathrm{D}$ value is lower than the -146 to $-112 \%$ values previously reported for amphiboles from other early Tertiary meteoric-hydrothermal systems in East Greenland and Scotland, indicating that the meteoric waters at Kap Edvard Holm were isotopically lighter than typical early Tertiary meteoric waters in the North Atlantic region. This probably reflects local climatic variations caused by formation of a major topographic dome at about the time of plutonism and hydrothermal activity. The calculated isotopic composition of the meteoric water is $\delta \mathrm{D}=-110 \pm 10 \%, \delta^{18} \mathrm{O} \approx-15 \%$. Igneous hornblendes and phlogopites from pegmatitic pods in hornfelsed basaltic xenoliths have $\delta^{18} \mathrm{O}$ values between -6.0 and $-3.8 \%$ and $\delta \mathrm{D}$ values between -155 and $-140 \%$. These are both much lower than typical
\end{abstract}

\section{E. Brandriss $\cdot$ R. J. Nevle $\cdot$ D. K. Bird ${ }^{1}$}

Department of Geological and Environmental Sciences, Stanford University, Stanford, CA, 94305-2115, USA

\section{J. R. O’Neil ( $\triangle)$}

Department of Geological Sciences, 1006 C.C. Little Building, University of Michigan, Ann Arbor, MI, 48109, USA

${ }^{1}$ Current address: Danish Lithosphere Centre, Oester Voldgade 10, DK-1350 Copenhagen K, Denmark.

Editorial responsibility: T. L. Grove values of fresh basalts. The oxygen isotope fractionations between pegmatitic hornblendes and surrounding hornfelsic minerals are close to equilibrium fractionations for magmatic temperatures, indicating that the pegmatites crystallized from low- $\delta^{18} \mathrm{O}$ partial melts of xenoliths that had been hydrothermally altered and depleted in ${ }^{18} \mathrm{O}$ prior to stoping. The pegmatitic minerals may have crystallized with low primary $\delta \mathrm{D}$ values inherited from the altered country rocks, but these values were probably overprinted extensively by subsolidus isotopic exchange with low $-\delta \mathrm{D}$ meteoric-hydrothermal fluids. This exchange was facilitated by rapid self-diffusion of hydrogen through the crystal structures. Primary igneous hornblendes from the plutonic rocks have $\delta^{18} \mathrm{O}$ values between +2.0 and $+3.2 \%$ and $\delta \mathrm{D}$ values between -166 and $-146 \%$. The ${ }^{18} \mathrm{O}$ fractionations between hornblendes and coexisting augites are close to equilibrium fractionations for magmatic temperatures, indicating that the hornblendes crystallized directly from the magma and subsequently underwent little or no oxygen exchange. The hornblendes may have crystallized with low primary $\delta \mathrm{D}$ values, due to contamination of the magma with altered xenolithic material, but the final $\delta \mathrm{D}$ values were probably controlled largely by subsolidus isotopic exchange. This inference is based partly on the observation that coexisting plagioclase has been extensively depleted in ${ }^{18} \mathrm{O}$ via a mineral-fluid exchange reaction that is much slower than the hydrogen exchange reaction in hornblende. It is concluded that all hydrous minerals in the study area, whether igneous or secondary, have $\delta \mathrm{D}$ values that reflect extensive subsolidus isotopic equilibration with meteoric-hydrothermal fluids.

\section{Introduction}

The Early Tertiary lavas and plutons exposed in Scotland, Ireland, and eastern Greenland are among the 


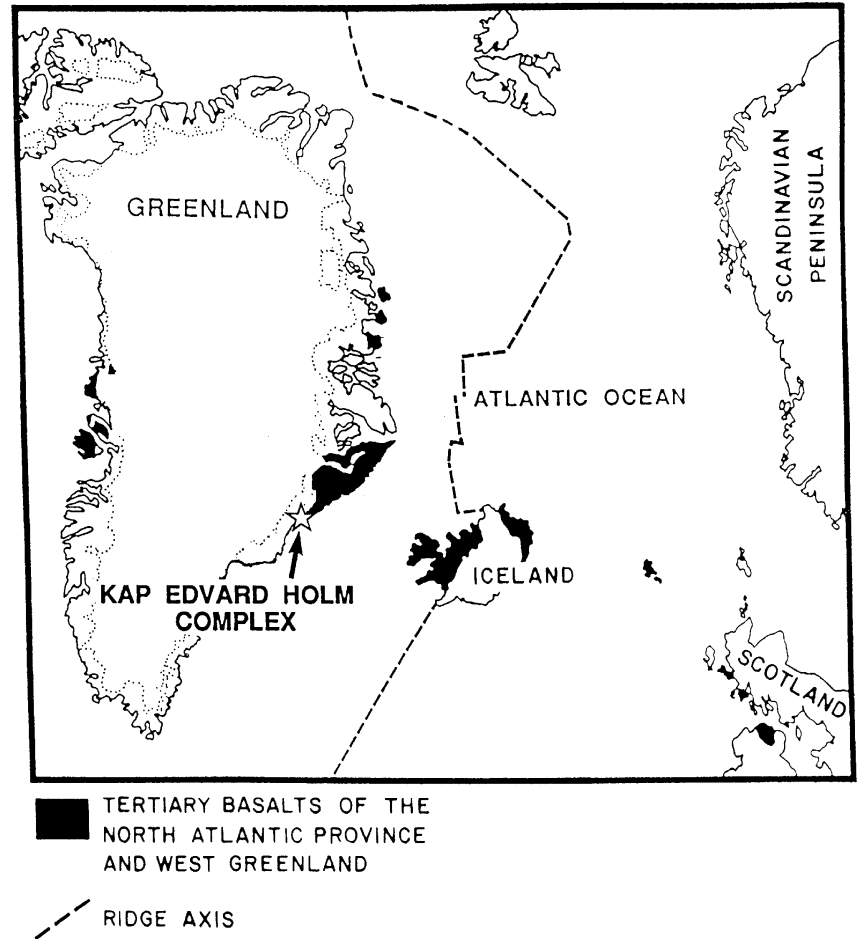

Fig. 1 Map of the North Atlantic Tertiary Igneous Province

oldest rocks of the North Atlantic Tertiary Igneous Province (Fig. 1). Most igneous activity in these areas took place between 64 and 50 million years ago, during an episode of voluminous basaltic magmatism that began shortly before the onset of rifting in the modern North Atlantic ocean basin (Soper et al. 1976; Nielsen et al. 1981; Bott 1987; Mussett et al. 1988; Noble et al. 1988). Basaltic magmatism was followed by comparatively minor silicic plutonism, which continued until approximately $30 \mathrm{Ma}$ in eastern Greenland (Gleadow and Brooks 1979; Noble et al. 1988).

Most of these Tertiary rocks have been altered by low $-\delta^{18} \mathrm{O}$, low- $\delta \mathrm{D}$ hydrothermal fluids of meteoric origin. This subsolidus alteration produced secondary minerals with anomalously low values of $\delta^{18} \mathrm{O}$ and $\delta \mathrm{D}$, and commonly left relict igneous minerals depleted in ${ }^{18} \mathrm{O}$ (Taylor and Forester 1971, 1979; Forester and Taylor 1976, 1977; Sheppard et al. 1977; Farver and Giletti 1989; Rose 1989; Fehlhaber and Bird 1991; Nevle et al. 1994; Manning and Bird 1995). Hydrogen and oxygen isotope compositions of secondary minerals in the altered rocks have been used to calculate the isotopic compositions of paleo-hydrothermal fluids, and of the meteoric waters from which these fluids were derived. Resulting estimates of Eocene meteoric water compositions in the North Atlantic region have ranged from $\delta \mathrm{D} \approx-85 \%$ and $\delta^{18} \mathrm{O} \approx-12 \%$ in Scotland (Forester and Taylor 1977) to $\delta \mathrm{D} \approx-100 \%$ and $\delta^{18} \mathrm{O} \approx-14 \%$ in eastern Greenland (Taylor and Forester 1979).
This paper presents hydrogen and oxygen isotope analyses of hydrous minerals from mafic rocks of the Kap Edvard Holm intrusive complex, an Eocene plutonic center on the east coast of Greenland. These data suggest that, during subsolidus alteration, igneous and secondary amphiboles exchanged hydrogen with low $-\delta \mathrm{D}$ hydrothermal fluids of meteoric origin. These fluids were derived from Eocene meteoric waters that were isotopically lighter than any Early Tertiary meteoric waters previously inferred for the region.

Geologic setting

The Kap Edvard Holm Complex is located $15 \mathrm{~km}$ southwest of the Skaergaard intrusion in the Kangerdlugssuaq area of East Greenland (Fig. 2). It consists mainly of layered gabbros, intruded locally by mafic dikes and syenitic plutons (Deer and Abbott 1965; Elsdon 1969, 1972; Abbott and Deer 1972; Deer et al. 1984; Bernstein et al. 1992). The gabbros are hosted by Precambrian gneisses to the north and west and by Paleocene basaltic lavas to the south and east. The basalts overlie the gneisses stratigraphically, and the present exposure pattern reflects southeastward tilting of the area following emplacement of the gabbro complex (Elsdon 1969; Abbott and Deer 1972).

The study area comprises a group of cliffs consisting mainly of layered olivine gabbro, located near the western margin of the complex. These cliffs are referred to collectively as "Stand and Deliver Nunatak" (Fig. 3). Igneous hornblende from this locality has yielded ${ }^{40} \mathrm{Ar} /{ }^{39} \mathrm{Ar}$ ages ranging from 49 to $50 \mathrm{Ma}$ (Nevle et al., 1994). The layered gabbro at Stand and Deliver Nunatak contains abundant xenoliths of hornfelsed metabasalt, and hosts numerous discordant bodies of massive gabbro and peridotite. These rocks contain hydrous minerals of both igneous and secondary origin.

Xenoliths

Xenoliths constitute roughly $10 \%$ of outcrop in the study area and occur as flat-lying slabs up to $5 \mathrm{~m}$ thick and $>100 \mathrm{~m}$ long. They

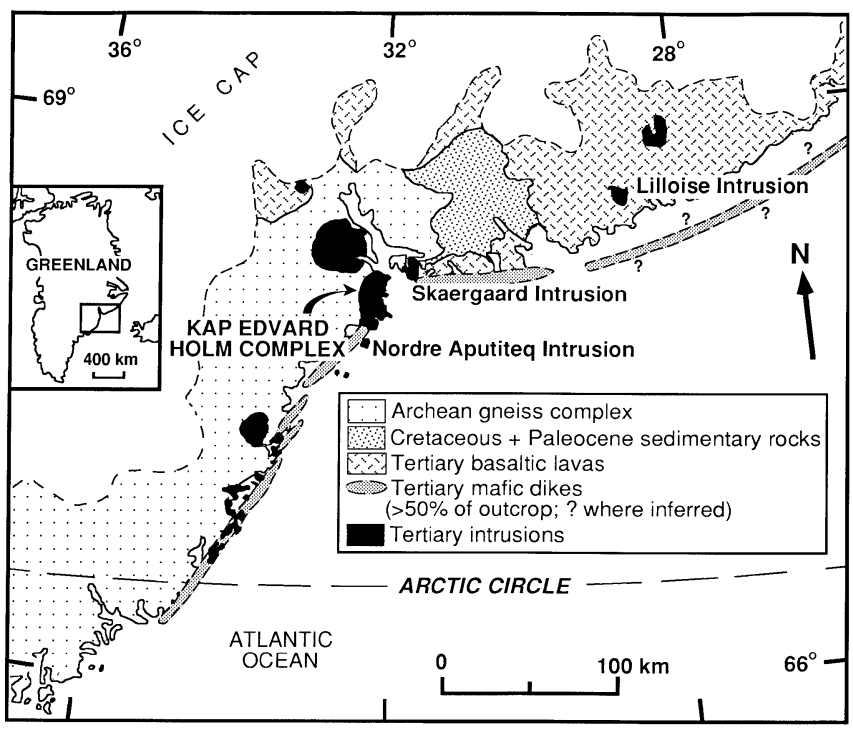

Fig. 2 The central east coast of Greenland, showing the Kap Edvard Holm Complex and other intrusions referred to in the text 


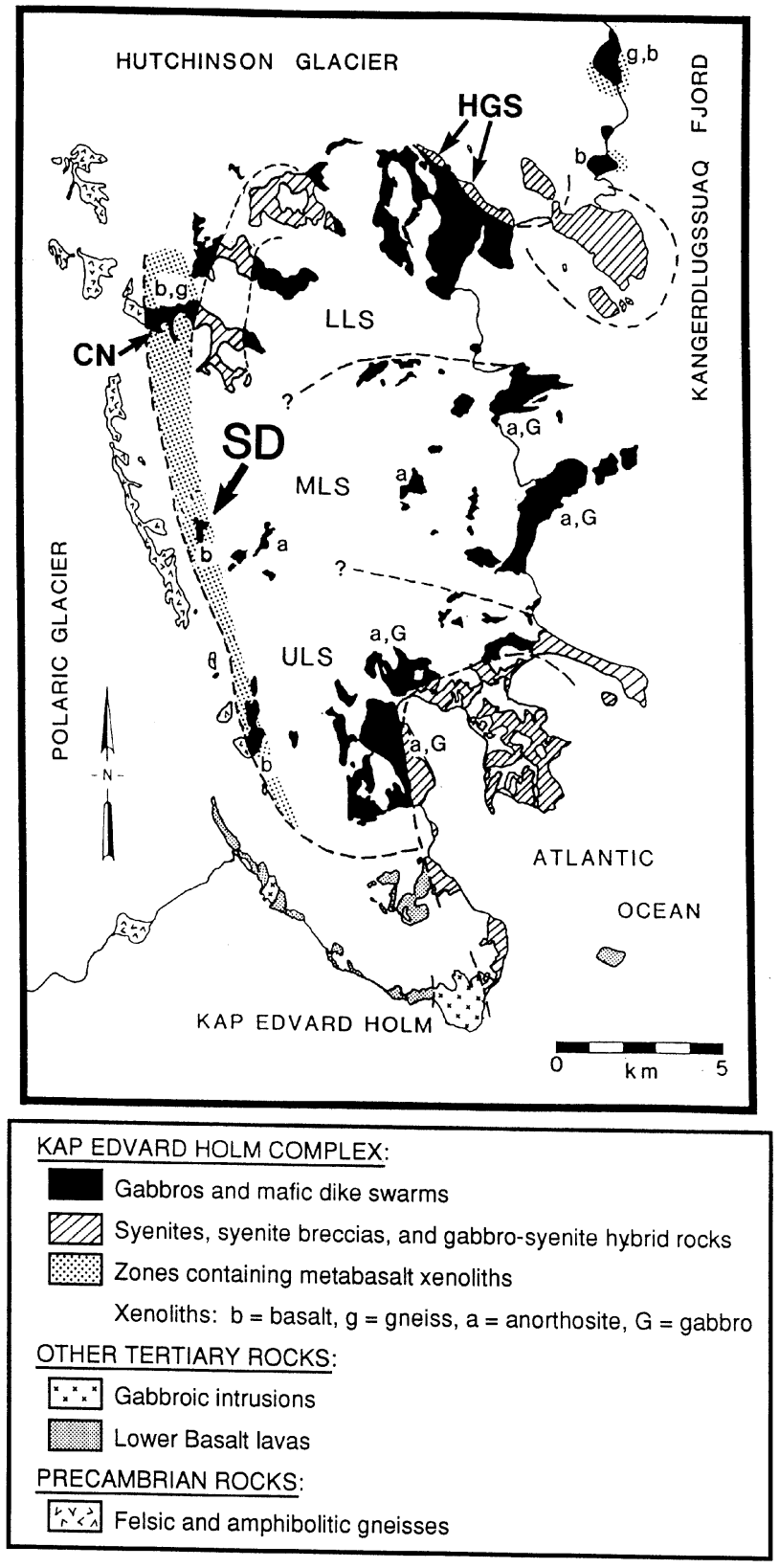

Fig. 3 Map of the Kap Edvard Holm Complex, showing the locations of Stand and Deliver Nunatak $(S D)$, Contact Nunatak $(C N)$, and the Hutchinson Glacier syenites $(H G S)$. The layered gabbros are divided into Lower, Middle and Upper Layered Series $(L L S, M L S$ and $U L S$; after Abbott and Deer 1972)

consist of metabasaltic country rock that has been hornfelsed to assemblages of augite + plagioclase + magnetite \pm olivine \pm orthopyroxene \pm ilmenite. Two-pyroxene thermometry gives recrystallization temperatures of roughly $1050^{\circ} \mathrm{C}$ (Brandriss 1993). Most xenoliths have been strongly depleted in incompatible elements due to partial melting (Brandriss 1993), and some enclose small pods of pegmatite that crystallized from the partial melts. These pods contain centimeter to decimeter-sized crystals of magnesiohornblende and phlogopite (Fig. 4A).

The xenoliths are fragments of Tertiary basaltic lava from a volcanic unit known as the Lower Basalts (the Lower Basalts have been studied by Nielsen et al. 1981; Holm 1988; Gill et al. 1988; Manning and Bird 1991, 1995; Manning et al. 1993; and Fram 1994). Throughout the region, the Lower Basalts have been altered to secondary mineral assemblages under conditions ranging from the zeolite facies in regionally metamorphosed rocks to the sanidinite facies in contact metamorphic aureoles (Bird et al. 1988a; Manning et al. 1993; Manning and Bird 1995). Alteration occurred in the presence of isotopically light meteoric-hydrothermal fluids which depleted the metabasalts in ${ }^{18} \mathrm{O}$ and deuterium (Taylor and Forester 1979; Manning and Bird 1995): whole-rock analyses have yielded $\delta^{18} \mathrm{O}$ values as low as $-2.3 \%$ (Taylor and Forester 1979) and $\delta \mathrm{D}$ values as low as $-136 \%$ (Brandriss 1993). The xenoliths contain hornfelsic plagioclase and augite with $\delta^{18} \mathrm{O}$ values as low as $-5.2 \%$ and $-5.5 \%$ respectively, reflecting their derivation from this hydrothermally altered and ${ }^{18} \mathrm{O}$-depleted protolith (Brandriss et al. 1992; Brandriss 1993). The water contained in hydrous secondary minerals in the metabasalts probably facilitated partial melting in the xenoliths (Brandriss 1993).

Postcumulus bodies

Late-magmatic recrystallization locally resulted in the replacement of layered gabbroic cumulates by discordant bodies of feldspathic peridotite and magnetite-rich gabbro. This occurred in response to localized influxes of $\mathrm{H}_{2} \mathrm{O}$, which caused destabilization of the primary cumulus assemblage (Brandriss 1993). The replacement bodies are spatially associated with metabasaltic xenoliths, indicating that some of the water was probably supplied by devolatilization or dehydration-melting of xenoliths within the cumulus pile. The postcumulus peridotites and gabbros typically contain several per cent primary igneous magnesiohornblende as intergranular or poikilitic crystals (Figs. 4B,C)

Some of the postcumulus rocks contain small dikes of hornblende-andesine pegmatite, which appear to have crystallized from late-magmatic segregations of evolved intercumulus liquid. These dikes contain blades of igneous magnesiohornblende up to a centimeter thick and a few centimeters long (Fig. 4D).

\section{Secondary alteration}

All rocks in the study area contain secondary hydrous minerals. The most common secondary assemblage consists of actinolite, chlorite, talc, magnetite, and orthoamphibole. This is similar to the actinolitic hornblende + chlorite + talc alteration type previously described in the Kap Edvard Holm Complex by Bird et al. (1988b). Maximum temperatures of formation for this assemblage are inferred to have been $500-600^{\circ} \mathrm{C}$ (Bird et al. 1988b). A less common assemblage, occurring mainly in the most altered gabbros, consists of epidote, albite, actinolite, chlorite, sericite, and titanite, sometimes with minor hedenbergite or hornblende. This is equivalent to the calcic amphibole + epidote + albite assemblage of Bird et al. (1988b), for which they inferred metamorphic temperatures of $380-500^{\circ} \mathrm{C}$. The pegmatites and magnetite-rich gabbros are generally the most altered rocks, containing up to $80 \%$ and $50 \%$ secondary minerals respectively (Figs. 4C,D). Other rock types typically contain 1-10\% secondary minerals.

Macroscopic hydrothermal veins filled with secondary minerals are present in many outcrops. Most veins contain actinolitic hornblende + chlorite + talc assemblages, but a few contain calcic amphibole + epidote + albite assemblages (Fig. 4E).

\section{Analytical methods}

Hydrogen and oxygen isotope analyses of mineral separates were performed at the University of Michigan. Oxygen was extracted by 

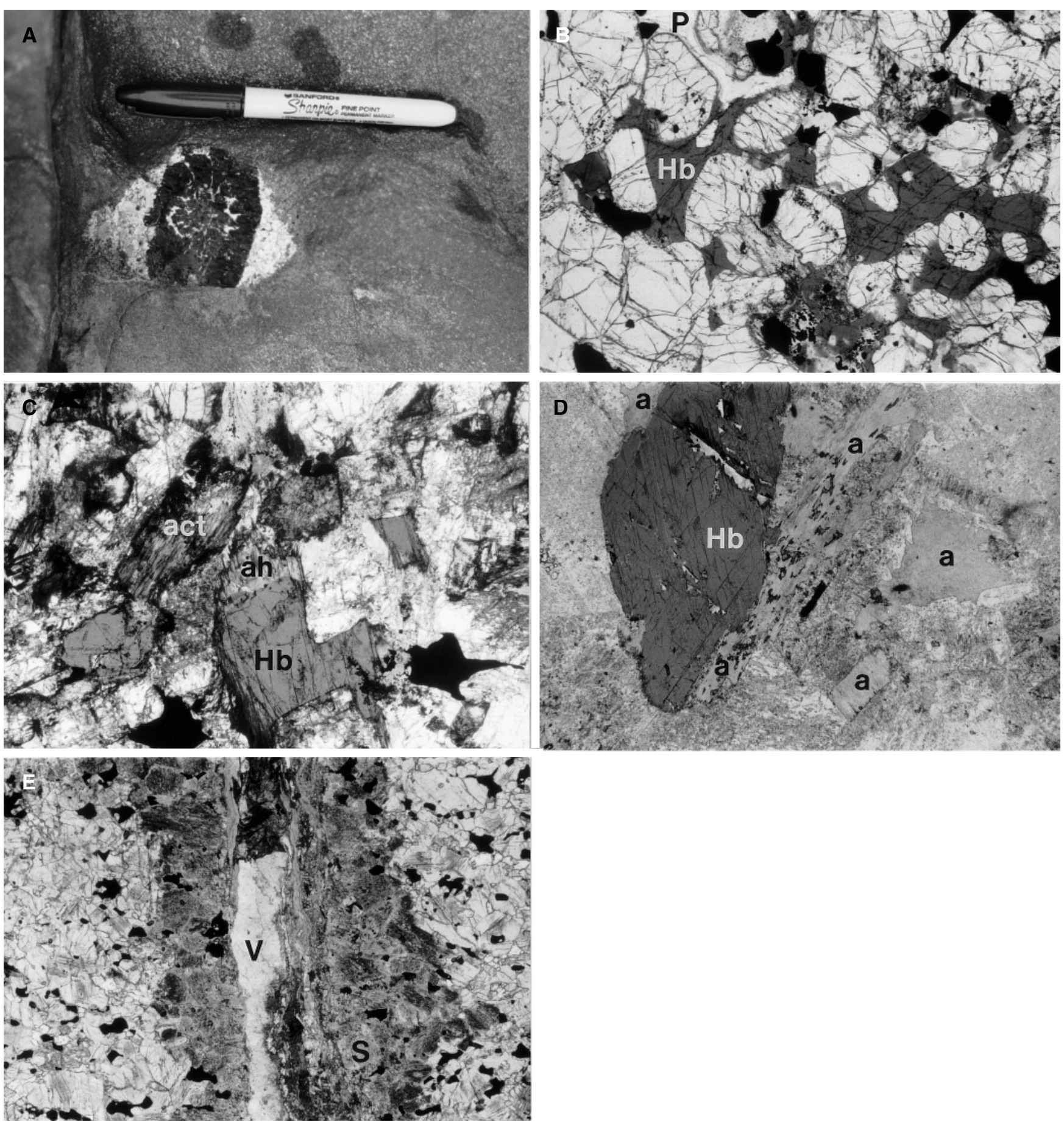

Fig. 4A-E Hydrous minerals in the various rock types. A Pegmatitic pod in hornfelsed metabasalt xenolith. The xenolith takes up the full field of view; the pod contains a single crystal of hornblende (black) flanked by patches of medium-grained plagioclase (white). The dark spots above the pen are raindrops. B Postcumulus peridotite (sample KEH406B). Equant olivine crystals are enclosed in poikilitic hornblende $(H b)$ and plagioclase $(P)$. Field of view $6 \mathrm{~mm}$ wide. C Postcumulus massive gabbro (sample KEH414). Intergranular hornblende $(\mathrm{Hb})$ is partially replaced by secondary actinolitic

hornblende $(a h)$ and fibrous actinolite (act) intergrown with secondary chlorite. Field of view $6 \mathrm{~mm}$ wide. D Pegmatitic dike (sample KEH402A) containing a hornblende megacryst $(\mathrm{Hb})$ surrounded by secondary actinolite $(a)$ and sericitized plagioclase (most of the area). Field of view $6 \mathrm{~mm}$ wide. E Hydrothermal vein cutting hornfelsed metabasalt xenolith (sample KEH259E). The vein center $(V)$ consists mainly of actinolite, actinolitic hornblende and epidote, while the selvedge $(S)$ contains abundant actinolite, epidote and chlorite. Field of view $6 \mathrm{~mm}$ wide 
reaction with $\mathrm{BrF}_{5}$, using a method similar to that of Clayton and Mayeda (1963). The reproducibility of oxygen analyses was typically better than $\pm 0.2 \%$. Hydrogen isotope analyses were done by the $\mathrm{Zn}$ reduction method of Vennemann and O'Neil (1993), and included determination of water by mass spectrometer voltage calibration. Hydrogen analyses were typically reproducible to within $\pm 2 \%$, although a few anomalous values were obtained during multiple analyses of some samples. The chemical compositions of amphiboles and micas were determined by wavelength-dispersive electron microprobe analysis of polished thin sections at Stanford University. Results of isotope analyses are presented in Table 1, and mineral compositions are presented in Table 2 .

\section{Results}

All of the hydrous minerals, whether igneous or secondary, have $\delta \mathrm{D}$ and $\delta^{18} \mathrm{O}$ values that are substantially lower than those of mantle-derived basaltic magmas. As earlier studies have shown for other igneous rocks in the region, these low values reflect the isotopic signature of meteoric water (e.g. Sheppard et al. 1977; Taylor and Forester 1979). The secondary minerals from Stand and Deliver Nunatak typically have $\delta \mathrm{D}$ values between -163 and $-138 \%$ and $\delta^{18} \mathrm{O}$ values between -5.8 and $-5.5 \%$. For comparison, typical mantle values are roughly $-80 \%$ and +5 to $+7 \%$ respectively (Kyser 1986). Igneous minerals from the metabasaltic xenoliths are isotopically similar to the secondary minerals, with $\delta \mathrm{D}$ values of -155 to $-139 \%$ and $\delta^{18} \mathrm{O}$ values of -6.0 to $-3.8 \%$. Igneous hornblendes from the postcumulus plutonic rocks have similar $\delta \mathrm{D}$ values $\left(-166\right.$ to $\left.-146^{\circ} \%\right)$ but somewhat higher $\delta^{18} \mathrm{O}$ values $(+2.0$ to $+3.2 \%)$. Even the highest values, however, are substantially lower than those of "normal" basaltic magmas. The isotopic signature of meteoric water is thus clearly discernible in all hydrous minerals from the study area. The nature and timing of interactions between magmas, rocks and meteoric waters can be elucidated through analysis of the data presented below.

\section{Secondary minerals}

Most of the secondary minerals are finely intergrown and difficult to separate. In one case, however, it was possible to extract pure secondary actinolite from an altered pegmatitic dike (sample KEH402A). This actinolite had a $\delta^{18} \mathrm{O}$ value of $-5.5 \%$ and a $\delta \mathrm{D}$ value of $-158 \%$, clearly reflecting alteration by isotopically light hydrothermal fluids of meteoric origin (e.g. Taylor 1974, 1977; Criss and Taylor 1986). Primary igneous hornblende from the same rock had $\delta^{18} \mathrm{O}=+3.0 \%$, a value more typical of igneous minerals.

The $\delta \mathrm{D}$ of the secondary actinolite can be used to calculate the $\delta \mathrm{D}$ of the hydrothermal fluid with which it equilibrated. The low $\delta^{18} \mathrm{O}$ value of the actinolite indicates that the amount of fluid was sufficient to alter the oxygen isotope composition of the rock substantially. This implies that the amount of hydrogen in the fluid must have been far greater than the amount in the rock, because rocks are rich in oxygen but poor in hydrogen. The $\delta \mathrm{D}$ of the fluid therefore could not have been modified greatly by water-rock interaction, and as a result, the original $\delta \mathrm{D}$ of the meteoric water can be calculated from the measured $\delta \mathrm{D}$ of the actinolite with which it equilibrated. Assuming equilibration temperatures between 380 and $600^{\circ} \mathrm{C}$, and taking into account the effects of amphibole composition (Table 2), the amphibole-water fractionation equation of Suzuoki and Epstein (1976) yields a $\delta \mathrm{D}$ value of $-110 \pm 10 \%$ for the meteoric water. The corresponding $\delta^{18} \mathrm{O}$ of this meteoric water would have been approximately $-15 \%$ (Craig 1961).

These results are corroborated by analyses of two samples of finely intergrown actinolite and chlorite. These samples (both from the same rock, but with different proportions of the two minerals) contained 3.4 and $7.3 \mathrm{wt} \% \mathrm{H}_{2} \mathrm{O}$ with $\delta \mathrm{D}$ values of -153 and $-138 \%$, respectively. The $\delta^{18} \mathrm{O}$ of the second sample was $-5.5 \%$. The low values are once again diagnostic of meteoric-hydrothermal alteration. The $\delta \mathrm{D}$ values for the two minerals can be crudely estimated from mass balance calculations by assuming that the chlorite contained $\sim 11 \mathrm{wt} \% \mathrm{H}_{2} \mathrm{O}$ and the actinolite contained $\sim 2 \quad \mathrm{wt} \% \mathrm{H}_{2} \mathrm{O}$. This yields values of $\delta \mathrm{D}_{\text {actinolite }} \approx-170 \%$ and $\delta \mathrm{D}_{\text {chlorite }} \approx-135 \%$, roughly consistent with the value obtained for the sample of pure actinolite.

The isotopic composition of another sample is somewhat anomalous. This sample (KEH259E) is a mm-wide hydrothermal vein containing actinolite, chlorite, epidote, and minor actinolitic hornblende (Fig. 4E). Petrographically, it is notably dissimilar to most veins in the study area, which are very thin $(\ll 1 \mathrm{~mm})$ and contain no epidote. A sample of nearly pure epidote from the vein selvedge yielded $\delta \mathrm{D}=-75 \%$, and a mixture of epidote and actinolite from within the vein yielded $\delta \mathrm{D}=-109 \%$. The relative proportions of minerals in the mixture can be calculated from x-ray $\mathrm{K} \alpha$ peak heights determined by powder diffractometry, using the absorption-diffraction method applied to a binary mixture (Snyder and Bish 1989, Eq. 22). This yields a rough estimate of $\sim 25$ wt $\%$ epidote and $\sim 75 \mathrm{wt} \%$ actinolite. Mass balance calculations (based on these proportions and on the measured $\delta \mathrm{D}$ of the pure epidote) give an approximate $\delta \mathrm{D}$ value of $-120 \%$ for the actinolite. This relatively high value could be due to localized alteration by a fluid that was isotopically heavier than that inferred from the other samples, possibly indicating a separate and isotopically distinct alteration event. It must be emphasized, however, that this is a rare type of vein, containing a secondary assemblage that is mineralogically distinct from the dominant type of alteration in the area. 
Table 1 Isotope analyses of hydrous minerals from Stand and Deliver Nunatak ${ }^{\mathrm{a}}$

Secondary minerals

\begin{tabular}{|c|c|c|c|c|c|}
\hline Sample & Mineral & Rock type & $\delta \mathrm{D}$ & $\delta^{18} \mathrm{O}^{\mathrm{b}}$ & $\mathrm{wt}^{\circ} \% \mathrm{H}_{2} \mathrm{O}^{\mathrm{c}}$ \\
\hline KEH259E & $\begin{array}{l}\text { Actinolite }+ \text { epidote } \\
\text { Epidote }\end{array}$ & $\begin{array}{l}\text { Hydrothermal vein } \\
\text { Hydrothermal vein }\end{array}$ & $\begin{array}{r}-109 \\
-75\end{array}$ & & $\begin{array}{l}2.00 \\
1.60\end{array}$ \\
\hline KEH402A & $\begin{array}{l}\text { Actinolite } \\
\text { Actinolite } \\
\text { Actinolite } \\
\text { Actinolite } \\
\text { Actinolite }\end{array}$ & $\begin{array}{l}\text { Pegmatitic dike } \\
\text { Pegmatitic dike } \\
\text { Pegmatitic dike } \\
\text { Pegmatitic dike } \\
\text { Pegmatitic dike }\end{array}$ & $\begin{array}{l}-161 \\
-158 \\
-158 \\
-163 \\
-150\end{array}$ & $-5.8(4)$ & $\begin{array}{l}1.99 \\
2.05 \\
2.04 \\
1.97 \\
2.01\end{array}$ \\
\hline KEH414 & $\begin{array}{l}\text { Actinolite }+ \text { chlorite } \\
\text { Actinolite }+ \text { chlorite }\end{array}$ & $\begin{array}{l}\text { Postcumulus gabbro } \\
\text { Postcumulus gabbro }\end{array}$ & $\begin{array}{l}-138 \\
-153\end{array}$ & $-5.5(1)$ & $\begin{array}{l}7.30 \\
3.39\end{array}$ \\
\hline
\end{tabular}

Igneous minerals in plutonic rocks

\begin{tabular}{|c|c|c|c|c|c|}
\hline Sample & Mineral & Rock type & $\delta \mathrm{D}$ & $\delta^{18} \mathrm{O}^{\mathrm{b}}$ & $\mathrm{wt} \% \mathrm{H}_{2} \mathrm{O}^{\mathrm{c}}$ \\
\hline KEH303I & Magnesiohornblende & Pegmatitic dike & -150 & $2.0(2)$ & 0.90 \\
\hline KEH402A & $\begin{array}{l}\text { Magnesiohornblende } \\
\text { Magnesiohornblende } \\
\text { Magnesiohornblende } \\
\text { Magnesiohornblende }\end{array}$ & $\begin{array}{l}\text { Pegmatitic dike } \\
\text { Pegmatitic dike } \\
\text { Pegmatitic dike } \\
\text { Pegmatitic dike }\end{array}$ & $\begin{array}{l}-152 \\
-146 \\
-148 \\
-160\end{array}$ & $3.0(2)$ & $\begin{array}{l}1.02 \\
1.02 \\
1.06 \\
1.05\end{array}$ \\
\hline KEH289 & Magnesiohornblende & Postcumulus peridotite & -146 & & 1.62 \\
\hline KEH303C & Magnesiohornblende & Postcumulus peridotite & -166 & $2.3(3)$ & 1.40 \\
\hline KEH406B & Magnesiohornblende & Postcumulus peridotite & -161 & $3.2(3)$ & 1.51 \\
\hline KEH407 & $\begin{array}{l}\text { Magnesiohornblende } \\
\text { Magnesiohornblende }\end{array}$ & $\begin{array}{l}\text { Layered gabbro, replaced } \\
\text { partially by peridotite }\end{array}$ & $\begin{array}{l}-160 \\
-158\end{array}$ & $3.0(2)$ & $\begin{array}{l}1.46 \\
1.45\end{array}$ \\
\hline KEH414 & Magnesiohornblende & Postcumulus gabbro & -159 & $2.9(2)$ & 1.18 \\
\hline
\end{tabular}

Igneous minerals in pegmatitic pods enclosed in xenoliths

\begin{tabular}{|c|c|c|c|c|c|}
\hline Sample & Mineral & Rock type & $\delta \mathrm{D}$ & $\delta^{18} \mathrm{O}^{\mathrm{b}}$ & $\mathrm{wt} \% \mathrm{H}_{2} \mathrm{O}^{\mathrm{c}}$ \\
\hline KEH259A & Magnesiohornblende & Pegmatitic pod in xenolith & -152 & $-6.0(2)$ & 1.16 \\
\hline KEH263 & Magnesiohornblende & Pegmatitic pod in xenolith & -154 & & 1.04 \\
\hline KEH274E & Magnesiohornblende & Pegmatitic pod in xenolith & -149 & & 0.84 \\
\hline KEH $274 \mathrm{~F}$ & $\begin{array}{l}\text { Magnesiohornblende } \\
\text { Magnesiohornblende } \\
\text { Magnesiohornblende }\end{array}$ & $\begin{array}{l}\text { Pegmatitic pod in xenolith } \\
\text { Pegmatitic pod in xenolith } \\
\text { Pegmatitic pod in xenolith }\end{array}$ & $\begin{array}{l}-155 \\
-155 \\
-155\end{array}$ & $-4.4(2)$ & $\begin{array}{l}0.65 \\
0.64 \\
0.72\end{array}$ \\
\hline KEH 290 & $\begin{array}{l}\text { Phlogopite } \\
\text { Phlogopite }\end{array}$ & $\begin{array}{l}\text { Pegmatitic pod in xenolith } \\
\text { Pegmatitic pod in xenolith }\end{array}$ & $\begin{array}{l}-142 \\
-139\end{array}$ & & $\begin{array}{l}1.50 \\
2.34\end{array}$ \\
\hline KЕH302 & $\begin{array}{l}\text { Magnesiohornblende } \\
\text { Magnesiohornblende } \\
\text { Phlogopite } \\
\text { Phlogopite }\end{array}$ & $\begin{array}{l}\text { Pegmatitic pod in xenolith } \\
\text { Pegmatitic pod in xenolith } \\
\text { Pegmatitic pod in xenolith } \\
\text { Pegmatitic pod in xenolith }\end{array}$ & $\begin{array}{l}-149 \\
-149 \\
-150 \\
-147\end{array}$ & $-3.8(2)$ & $\begin{array}{l}0.52 \\
0.51 \\
1.13 \\
1.17\end{array}$ \\
\hline
\end{tabular}

${ }^{a}$ All values for isotope analyses are reported in per mil relative to SMOW

${ }^{\mathrm{b}}$ Average of multiple analylses; the number of analyses is given in parentheses. Reproducibility was typically better than \pm 0.2 per mil

${ }^{c} \mathrm{H}_{2} \mathrm{O}$ contents determined by mass spectrometer voltage calibration (Vennemann and O'Neil 1993)

Igneous minerals in pegmatitic pods enclosed in xenoliths

Centimeter to decimeter-sized crystals of hornblende and phlogopite were separated from pegmatitic pods enclosed in mafic xenoliths. Hornblende megacrysts yielded $\delta^{18} \mathrm{O}$ values of $-6.0,-4.4$, and $-3.8 \%$. The unequivocally igneous textures of the pegmatitic horn- blendes suggest that these low $\delta^{18} \mathrm{O}$ values reflect crystallization from low $-\delta^{18} \mathrm{O}$ melts of the host xenoliths. This interpretation is supported by isotopic data for the enclosing hornfelses: the hornfels a few centimeters away from one pegmatitic body (sample KEH274F, $\delta^{18} \mathrm{O}_{\text {hornblende }}=-4.4 \%$ oo contains pyroxene with $\delta^{18} \mathrm{O}=-4.3 \%$ and plagioclase with $\delta^{18} \mathrm{O}=-3.8 \%$, yielding isotopic fractionations between hornblende, 
Table 2 Representative electron microprobe analyses of hydrous minerals $(H V$ hydrothermal vein cutting metabasalt xenolith, $P D$ pegmatitic dike, PER

postcumulus peridotite body, $M G$ postcumulus magnetite-rich gabbro body, XENO pegmatitic pod enclosed in metabasalt xenolith)

\begin{tabular}{|c|c|c|c|c|c|c|c|c|c|c|}
\hline \multirow{3}{*}{$\begin{array}{l}\text { Mineral } \\
\text { Rock type } \\
\text { Sample }^{\mathrm{b}}\end{array}$} & \multicolumn{5}{|c|}{ Secondary amphibole } & \multicolumn{5}{|c|}{ Igneous hornblende } \\
\hline & $H V^{a}$ & $\mathrm{PD}^{\mathrm{a}}$ & $\mathrm{MG}^{\mathrm{a}}$ & $\mathrm{MG}^{\mathrm{a}}$ & $\mathrm{MG}^{\mathrm{a}}$ & PER & PER $^{\mathrm{a}}$ & $\mathrm{PER}^{\mathrm{a}}$ & $\mathrm{PER}^{\mathrm{a}}$ & $\mathrm{MG}^{\mathrm{a}}$ \\
\hline & $259 \mathrm{E}$ & $402 \mathrm{~A}$ & 414 & 414 & 414 & 289 & $303 \mathrm{C}$ & $406 \mathrm{~B}$ & 407 & 414 \\
\hline $\mathrm{SiO}_{2}$ & 54.05 & 51.86 & 53.87 & 39.83 & 44.15 & 42.93 & 42.62 & 43.69 & 42.61 & 40.78 \\
\hline $\mathrm{TiO}_{2}$ & 0.09 & 0.08 & 0.23 & 0.16 & 0.36 & 4.00 & 3.70 & 4.09 & 4.05 & 3.90 \\
\hline $\mathrm{Al}_{2} \mathrm{O}_{3}$ & 0.94 & 0.49 & 1.42 & 11.45 & 10.27 & 10.78 & 10.30 & 10.11 & 10.61 & 10.05 \\
\hline $\mathrm{Cr}_{2} \mathrm{O}_{3}$ & 0.00 & 0.00 & 0.12 & 0.00 & 0.00 & 0.05 & 0.09 & 0.16 & 0.08 & 0.02 \\
\hline $\mathrm{FeO}^{\mathrm{c}}$ & 17.28 & 20.51 & 10.67 & 22.26 & 17.61 & 10.54 & 10.07 & 10.65 & 11.70 & 10.95 \\
\hline $\mathrm{MnO}$ & 0.31 & 0.28 & 0.15 & 0.39 & 0.33 & 0.17 & 0.07 & 0.13 & 0.20 & 0.09 \\
\hline $\mathrm{MgO}$ & 13.39 & 11.36 & 18.40 & 8.54 & 12.33 & 14.13 & 16.03 & 15.60 & 14.80 & 15.73 \\
\hline $\mathrm{CaO}$ & 12.54 & 12.03 & 12.71 & 12.15 & 12.24 & 11.58 & 11.45 & 11.30 & 11.56 & 11.91 \\
\hline $\mathrm{Na}_{2} \mathrm{O}$ & 0.11 & 0.14 & 0.23 & 1.90 & 1.83 & 2.43 & 2.71 & 2.48 & 2.18 & 2.20 \\
\hline $\mathrm{K}_{2} \mathrm{O}$ & 0.03 & 0.05 & 0.02 & 0.17 & 0.09 & 1.12 & 1.04 & 0.92 & 1.00 & 1.28 \\
\hline $\mathrm{Cl}^{2}$ & 0.00 & 0.00 & 0.03 & 0.65 & 0.26 & 0.03 & 0.04 & 0.03 & 0.04 & 0.06 \\
\hline$F^{d}$ & 0.00 & 0.00 & 0.06 & 0.00 & 0.41 & 0.12 & 1.09 & 0.58 & 0.52 & 1.30 \\
\hline Sum & 98.74 & 96.80 & 97.91 & 97.50 & 99.88 & 97.88 & 99.21 & 99.74 & 99.35 & 98.27 \\
\hline$X(\mathrm{Fe})^{\mathrm{e}}$ & 0.42 & 0.49 & 0.21 & 0.60 & 0.45 & 0.29 & 0.22 & 0.24 & 0.26 & 0.21 \\
\hline Mineral & \multicolumn{5}{|c|}{ Igneous hornblende } & \multicolumn{5}{|c|}{ Igneous phlogopite } \\
\hline Rock type & XENO & XENO & XENO & XENO & XENO & XENO & XENO & $\mathrm{XENO}^{\mathrm{a}}$ & XENO & XENO \\
\hline Sample $^{\mathrm{b}}$ & $259 \mathrm{~A}$ & 263 & $274 \mathrm{E}$ & $274 \mathrm{~F}$ & $274 \mathrm{~F}^{\mathrm{f}}$ & 302 & 3031 & $402 \mathrm{~A}$ & 290 & 302 \\
\hline $\mathrm{SiO}_{2}$ & 43.71 & 44.54 & 42.52 & 43.02 & 43.03 & 42.62 & 43.77 & 40.71 & 38.70 & 38.84 \\
\hline $\mathrm{TiO}_{2}$ & 2.79 & 3.11 & 3.72 & 3.78 & 3.82 & 3.81 & 3.52 & 3.80 & 5.79 & 6.03 \\
\hline $\mathrm{Al}_{2} \mathrm{O}_{3}$ & 9.88 & 10.01 & 10.37 & 10.70 & 10.76 & 10.46 & 9.90 & 9.88 & 12.95 & 13.15 \\
\hline $\mathrm{Cr}_{2} \mathrm{O}_{3}$ & 0.15 & 0.07 & 0.06 & 0.11 & & 0.03 & 0.00 & 0.06 & 0.08 & 0.11 \\
\hline $\mathrm{FeO}^{\mathrm{c}}$ & 8.64 & 8.81 & 9.13 & 8.38 & 8.52 & 8.72 & 10.40 & 11.79 & 11.25 & 9.82 \\
\hline $\mathrm{MnO}$ & 0.18 & 0.13 & 0.13 & $0.07]$ & $0.10]$ & 0.11 & 0.19 & 0.18 & 0.11 & 0.00 \\
\hline $\mathrm{MgO}$ & 16.28 & 16.08 & 15.57 & 16.11 & 16.31 & 16.17 & 14.73 & 15.25 & 17.07 & 17.43 \\
\hline $\mathrm{CaO}$ & 11.72 & 11.24 & 11.72 & 11.54 & 11.77 & 11.78 & 11.14 & 11.37 & 0.02 & 0.05 \\
\hline $\mathrm{Na}_{2} \mathrm{O}$ & 2.33 & 2.11 & 2.53 & 2.46 & 2.41 & 2.25 & 2.89 & 2.46 & 0.37 & 0.50 \\
\hline $\mathrm{K}_{2} \mathrm{O}$ & 0.75 & 0.56 & 1.10 & 0.82 & 0.94 & 1.47 & 0.71 & 1.01 & 9.15 & 9.02 \\
\hline $\mathrm{Cl}$ & 0.00 & 0.08 & 0.00 & 0.00 & & 0.00 & 0.00 & 0.04 & 0.05 & 0.01 \\
\hline$F^{d}$ & 0.63 & 0.65 & 1.01 & 0.70 & & 1.24 & 1.22 & 1.35 & 1.03 & 1.73 \\
\hline Sum & 97.06 & 97.39 & 97.86 & 97.69 & 97.66 & 98.66 & 98.47 & 97.90 & 96.57 & 96.69 \\
\hline$X(\mathrm{Fe})$ & 0.22 & 0.23 & 0.23 & 0.21 & 0.21 & 0.21 & 0.28 & 0.23 & 0.24 & 0.21 \\
\hline
\end{tabular}

a Analyses collected at the University of California, Davis. All other analyses were collected at Stanford University. A complete tabulation of data, and details of analytical methods, are presented by Brandriss (1993)

'All sample numbers have the prefix "KEH"

${ }^{c}$ All $\mathrm{Fe}$ as $\mathrm{FeO}$

${ }^{\mathrm{d}}$ Fluorine concentrations must be regarded as approximations due to poor reproducibility (for individual samples, F concentrations determined on the University of California, Davis microprobe were roughly twice as high as those determined on the Stanford University microprobe)

${ }^{\mathrm{e}} X(\mathrm{Fe})$ is the mole fraction of $\mathrm{Fe}$ in the octahedral sites. In the amphiboles, it is assumed that all five octahedral sites are occupied only by $\mathrm{Mg}, \mathrm{Fe}$, and $\mathrm{Ti}$, and that all $\mathrm{Mg}$ and Ti reside in octahedral sites ${ }^{\mathrm{f}} \mathrm{XRF}$ analysis of fused disk, with all $\mathrm{Fe}$ reported as $\mathrm{FeO}$. The actual $\mathrm{FeO}$ content of this sample was determined by wet chemistry using a slightly modified version of the technique of Wilson (1955); analysis in triplicate gave a value of $7.37 \pm 0.06 \% \mathrm{FeO}$ pyroxene and plagioclase that are almost identical to the predicted equilibrium values for temperatures of 900-1000 $\mathrm{C}$ (Bottinga and Javoy 1975; Matthews et al. 1983). This supports the inference that the pegmatites and hornfelses formed at high temperature from the same reservoir of ${ }^{18} \mathrm{O}$-depleted country-rock material, implying that the ${ }^{18} \mathrm{O}$ depletion occurred prior to stoping. Petrographic analysis of the hornfelses strongly supports this interpretation. The hornfelses are the least altered rocks in the study area, yet contain pyroxenes with $\delta^{18} \mathrm{O}$ values as low as $-5.5 \%$ (Brandriss et al. 1992; Brandriss 1993). Pyroxene is strongly resistant to subsolidus ${ }^{18} \mathrm{O}$ exchange (e.g. Criss and Taylor 1986), so the low $-\delta^{18} \mathrm{O}$ values must have been inherited from the country rock protolith. This is consistent with studies of the country rocks, which have shown 
that hydrothermal alteration produced abundant low $-\delta \mathrm{D}$ and low $-\delta^{18} \mathrm{O}$ secondary minerals in metabasalts throughout the region (e.g. Taylor and Forester 1979; Manning and Bird 1995).

The $\delta \mathrm{D}$ values of the pegmatitic hornblendes and phlogopites range from -155 to $-141 \%$, clearly reflecting the isotopic signature of meteoric water. The pegmatitic minerals crystallized from melts of hydrothermally altered, low $-\delta \mathrm{D}$ country rocks, so it is likely that they formed with low primary $\delta \mathrm{D}$ values. The measured values, however, are not necessarily the primary values. Hydrogen self-diffuses rapidly through these minerals (Cole et al. 1983; Graham et al. 1984), so the low $\delta \mathrm{D}$ values that were ultimately preserved could reflect a subsolidus hydrothermal overprint.

\section{Igneous minerals in plutonic rocks}

Igneous hornblendes from the plutonic rocks have $\delta^{18} \mathrm{O}$ values ranging from +2.0 to $+3.2 \%$. These are much higher than the values for secondary minerals, and are only a few per mil lower than "normal" values for mantle-derived igneous rocks. The slight shift from normal igneous values is probably attributable either to contamination of the parent magmas by low $-\delta^{18} \mathrm{O}$ xenolithic material, or to high-temperature subsolidus exchange of oxygen between isotopically "normal" igneous hornblende and $10 \mathrm{w}-\delta^{18} \mathrm{O}$ meteorichydrothermal fluids (Brandriss, 1993). Analyses of coexisting hornblende and augite yield $\delta^{18} \mathrm{O}_{\text {augite-hornblende }}$ fractionations of +0.6 to $-0.2 \%$, which are similar to equilibrium fractionations for temperatures of $500-1000^{\circ} \mathrm{C}(\approx 0$ to $0.5 \%$; Bottinga and Javoy 1975). This could potentially be consistent with either of the hypotheses mentioned above.

The $\delta \mathrm{D}$ values of the igneous hornblendes range from -166 to $-146 \%$. These are similar to the values of the secondary actinolites, but much lower than the values of mantle-derived basaltic magmas, indicating that most of the hydrogen must be of meteoric origin. This can potentially be explained by contamination of the magma with hydrothermally altered low $-\delta \mathrm{D}$ material (such as the basaltic xenoliths), by subsolidus exchange of hydrogen with meteoric-hydrothermal fluids, or by some combination of these processes.

\section{Discussion}

Origin of low $\delta \mathrm{D}$ values of hydrous minerals

The low $\delta \mathrm{D}$ values of secondary minerals from Stand and Deliver Nunatak are clearly attributable to subsolidus alteration by low $-\delta \mathrm{D}$ hydrothermal fluids of meteoric origin. The low $\delta \mathrm{D}$ values of igneous minerals, however, can potentially be explained in at least two ways: some may have crystallized directly from low $-\delta \mathrm{D}$ magmas, whereas others may have exchanged hydrogen with low $-\delta \mathrm{D}$ hydrothermal fluids.

Direct evidence for subsolidus hydrogen exchange is not readily identifiable in the igneous minerals. However, evidence for subsolidus oxygen exchange is clearly discernible in other igneous minerals from the same rocks. Brandriss (1993) showed that all of the hornblende-bearing peridotites and gabbros contain clear, fresh-looking plagioclase that has exchanged oxygen with low- $\delta^{18} \mathrm{O}$ meteoric-hydrothermal fluids, producing $\delta^{18} \mathrm{O}_{\text {plagioclase }}$ values as low as $-5.4 \%$. These values reflect subsolidus ${ }^{18} \mathrm{O}$ depletions of as much as 9.5\% (Fig. 5). If the intergranular hornblende in these rocks exchanged hydrogen with the fluid as readily as the plagioclase exchanged oxygen, then the final $\delta \mathrm{D}$ values of the hornblendes must have been controlled largely by subsolidus isotopic equilibration.

Rates of isotopic exchange between fluids and minerals are strongly dependent on exchange mechanisms (e.g. Cole and Ohmoto 1986). In feldspars, oxygen exchange is relatively rapid if it occurs by in situ dissolution and reprecipitation of mineral grains (O'Neil and Taylor 1967) but is orders of magnitude slower if it occurs by self-diffusion of oxygen through the crystal structure (Giletti et al. 1978; Giletti 1985). For the plagioclase analyzed in this study, several factors suggest that self-diffusion, rather than dissolution-reprecipitation, was the dominant mechanism of oxygen isotope exchange. The plagioclase is clear and fresh-looking in mineral separates and in thin sections, and many grains contain complex forms of primary compositional zoning that could not plausibly have survived secondary dissolution and reprecipitation (Fig. 6). In addition, at the high alteration temperatures inferred from secondary mineral assemblages, self-diffusion rates are sufficiently rapid that extensive oxygen exchange could easily have occurred during the lifetime of a large hydrothermal system (Giletti et al. 1978). It is therefore concluded that self-diffusion was the dominant mechanism of oxygen exchange in igneous plagioclase.

By comparing the self-diffusion coefficients for oxygen and hydrogen, we can determine the extent to which oxygen exchange in plagioclase would have been accompanied by hydrogen exchange in hornblende. Experiments have shown that the self-diffusion coefficient for hydrogen in hornblende is two to three orders of magnitude greater than the self-diffusion coefficient for oxygen in plagioclase (Giletti et al. 1978; Graham et al. 1984). This implies that the hornblende would have exchanged hydrogen much faster than the plagioclase exchanged oxygen. Therefore, given the evidence for extensive oxygen isotope exchange in plagioclase, the coexisting intergranular hornblendes could not have retained much of their original hydrogen. Instead, their final hydrogen isotope compositions were probably 


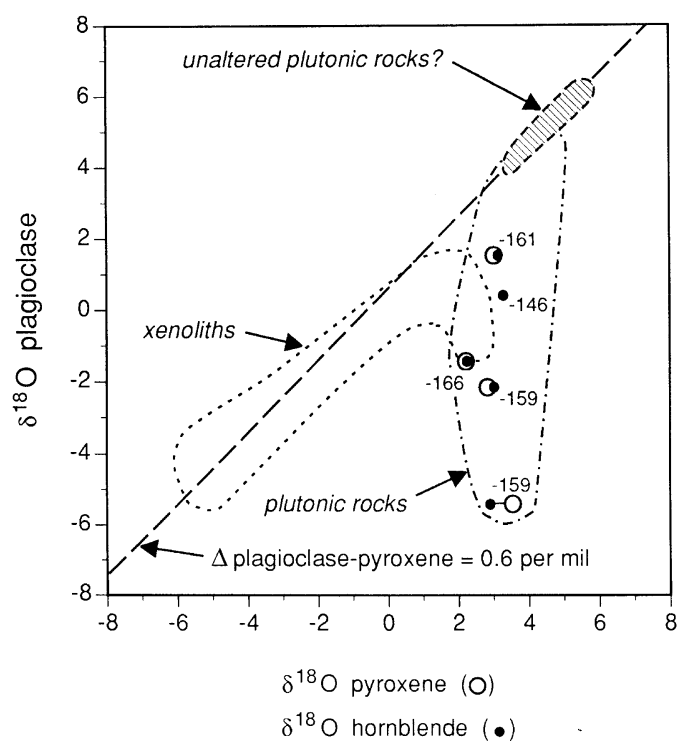

Fig. $5 \delta^{18} \mathrm{O}$ of plagioclase plotted against $\delta^{18} \mathrm{O}$ of coexisting pyroxene and hornblende, for samples from Stand and Deliver Nunatak. Symbols are shown only for those rocks (all plutonic) in which igneous hornblende was analyzed; the number beside each symbol is the $\delta \mathrm{D}$ value of the hornblende. Overlapping symbols, and symbols joined by a thin line, represent pairs of analyses from a single rock sample. The fields for xenoliths and plutonic rocks are for plagioclase-pyroxene pairs, and are taken from Brandriss (1993). The plagioclase-pyroxene fractionation line represents equilibrium at $\sim 950^{\circ} \mathrm{C}$ (Matthews et al. 1983). The vertical distance that an analysis falls below this line represents the minimum amount of subsolidus ${ }^{18} \mathrm{O}$ depletion in the plagioclase (e.g. Gregory et al. 1989). The "unaltered plutonic rocks?" field includes typical values for fresh basalts from around the world (Taylor 1974), but has been extended toward lower $\delta^{18} \mathrm{O}$ values to account for possible contamination of the magma with low $-{ }^{18} \mathrm{O}$ xenolithic material

controlled largely by subsolidus isotopic equilibration with meteoric-hydrothermal fluids.

The time required for hydrogen isotope exchange in hornblende can be estimated from experimentally determined diffusion coefficients, using the analytical expressions derived by Crank (1975). For the purposes of calculation, the minerals are assumed to have been enclosed in fluid. This is consistent with the observation that mineral grains in these rocks are commonly surrounded by grain-boundary microfractures lined with hydrous secondary minerals (Brandriss et al. 1992). It is also assumed that the amount of hydrogen in the fluid was much greater than the amount in the hornblende, so that the fluid can be treated as an infinite reservoir of hydrogen of constant isotopic composition. Sample calculations have been performed for a grain size of $0.4 \mathrm{~mm}$, which is about the size of hornblende-filled intergranular spaces in the peridotites and gabbros.

The calculated timescales required for measurable isotopic exchange are short compared to the lifetime of a large hydrothermal system (Fig. 7). The model hornblende exchanges $25 \%$ of its hydrogen within weeks at

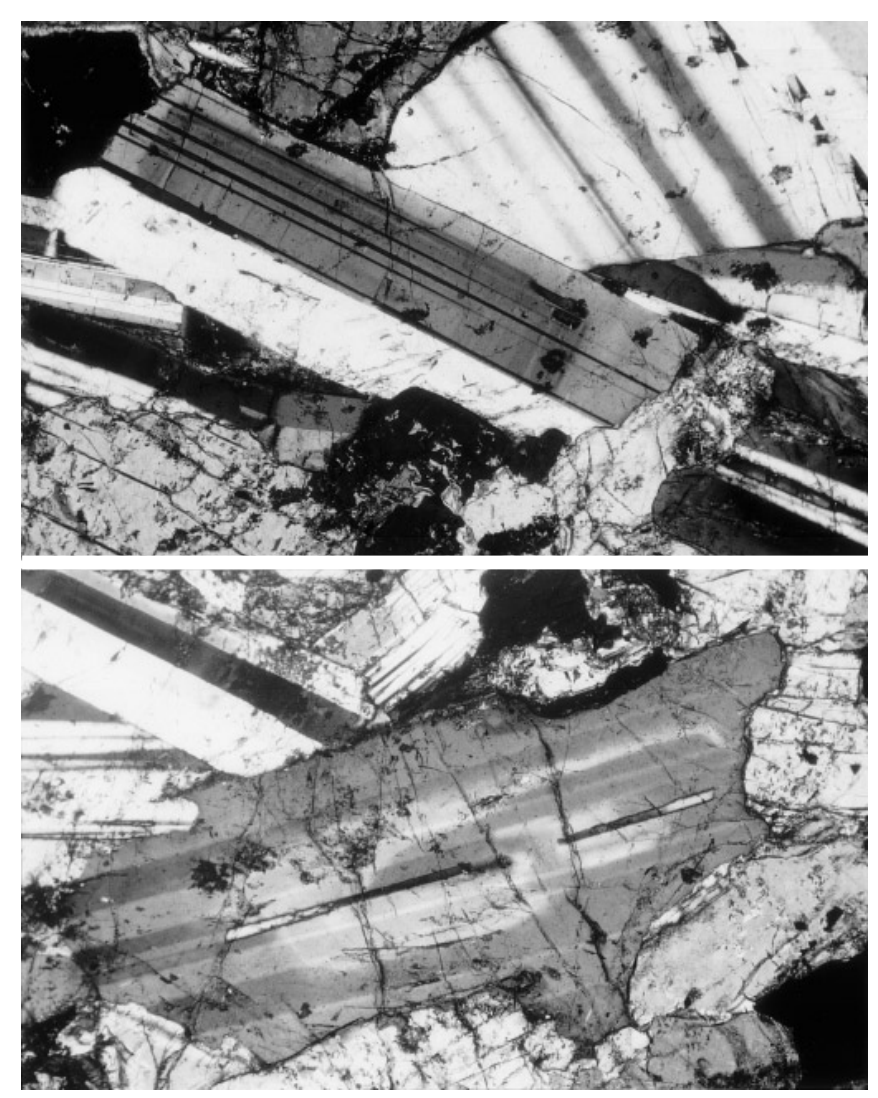

Fig. 6 Examples of complex igneous zoning in plagioclase, sample $\mathrm{KEH} 407$. Plagioclase and pyroxene in this rock have $\delta^{18} \mathrm{O}$ values of -2.6 and $+2.8 \%$, respectively. Assuming an initial plagioclase-pyroxene oxygen isotope fractionation of $0.5 \%$ in the crystallizing magma (Matthews et al. 1983), the measured values indicate subsolidus depletions of at least $5.9 \%$ in the plagioclase despite its fresh appearance and the widespread preservation of primary compositional zoning. Each field of view $3 \mathrm{~mm}$ wide

$800^{\circ} \mathrm{C}$, and within a few years at $500^{\circ} \mathrm{C}$. Nearly complete exchange occurs within several years at $800^{\circ} \mathrm{C}$, a reasonable temperature for the early post-magmatic stages of meteoric-hydrothermal circulation (Bird et al., 1988b). These results are consistent with the inference that primary intergranular hornblende could not have retained its original hydrogen during the alteration event. In contrast, the relatively high $\delta^{18} \mathrm{O}$ values for hornblende indicate that it was resistant to oxygen exchange, presumably because oxygen self-diffusion is several orders of magnitude slower than hydrogen self-diffusion in amphiboles (Graham et al. 1984; Farver and Giletti 1985).

Compared to the intergranular hornblende, the pegmatitic hornblende and phlogopite could have been more resistant to hydrogen exchange due to their much larger grain sizes. This might explain some of the variations in measured $\delta \mathrm{D}$ values. The pegmatitic crystals tend to have slightly higher $\delta \mathrm{D}$ values than the intergranular crystals, despite being otherwise similar in composition (Table 2; Fig. 8). If the magma had 


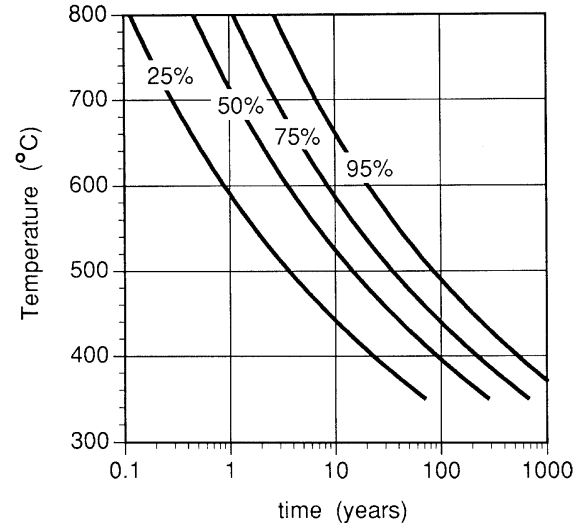

Fig. 7 Time required to achieve various amounts of hydrogen isotope exchange between hornblende and water. The labels on the curves refer to the fraction of hydrogen exchanged in a $0.4 \mathrm{~mm}$ grain of hornblende, assuming all diffusion occurs parallel to the $c$-axis (i.e. the hornblende grain is modeled as an infinite plate $0.4 \mathrm{~mm}$ thick). Curves are calculated from Figure 4.6 of Crank (1975), using the self-diffusion coefficients of Graham et al. (1984) and assuming that the water is an infinite reservoir of hydrogen. Experimentally measured diffusion coefficients (D) were extrapolated to $800^{\circ} \mathrm{C}$ by assuming a linear relationship between $\log \mathrm{D}$ and $1 / T$.

a higher $\delta \mathrm{D}$ value than later hydrothermal fluids, then greater retention of magmatic hydrogen in the pegmatitic crystals might account for some of the measured isotopic variation. Such a grain size effect could have been partially offset, however, by the presence of permeable microfractures within mineral grains (Fig. 9). Also, some of the isotopic variability might simply reflect localized variations in fluid composition or final isotopic equilibration temperature.

Despite such uncertainties, the low $\delta \mathrm{D}$ values indicate that most hydrogen in all of the igneous minerals was derived ultimately from the regional meteoric water. Partial melting of altered metabasalt, or assimilation of altered crust, could have produced low $-\delta \mathrm{D}$ magmas from which low $-\delta \mathrm{D}$ minerals crystallized. Subsolidus isotopic exchange with meteoric-hydrothermal fluids was probably ubiquitous, and would likewise have produced low (though not necessarily identical) $\delta \mathrm{D}$ values. It is possible that some igneous minerals crystallized with low primary $\delta \mathrm{D}$ values, and changed isotopic composition only slightly during subsolidus isotopic re-equilibration.

$\delta \mathrm{D}$ values in other parts of the Kap Edvard Holm Complex

Hydrogen and oxygen isotope compositions of secondary minerals in other parts of the Kap Edvard Holm complex have been measured by Fehlhaber and Bird (1991), Brandriss (1993), and Nevle et al. (1994). These studies have shown that the complex was affected by more than one major hydrothermal event.

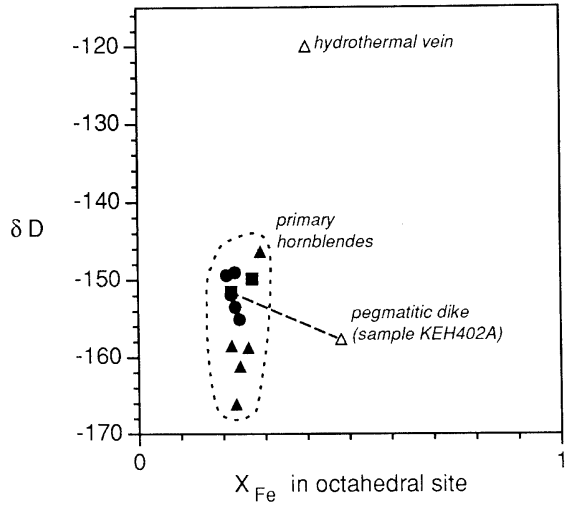

- Primary hornblende, pegmatitic pods enclosed in xenoliths
Primary intergranular hornblende, postcumulus peridotite
and gabbro
$\Delta$ Primary hornblende, postcumulus pegmatitic dikes
Secondary actinolite

Fig. 8 Values of $\delta D$ plotted against the mole fraction of octahedral sites occupied by iron (both $\mathrm{Fe}^{+2}$ and $\mathrm{Fe}^{+3}$ ) for amphibole samples from Stand and Deliver Nunatak. The dashed line joins secondary actinolite and primary hornblende that were separated from a single hand sample. The $\delta \mathrm{D}$ value for the vein-filling actinolite was calculated from analyses of actinolite-epidote mixtures (see text). Values of $\mathrm{X}_{\mathrm{Fe}}$ were calculated from the averages of multiple electron microprobe analyses (representative analyses are presented in Table 2). No attempt was made to estimate the proportions of $\mathrm{Fe}^{+2}$ and $\mathrm{Fe}^{+3}$

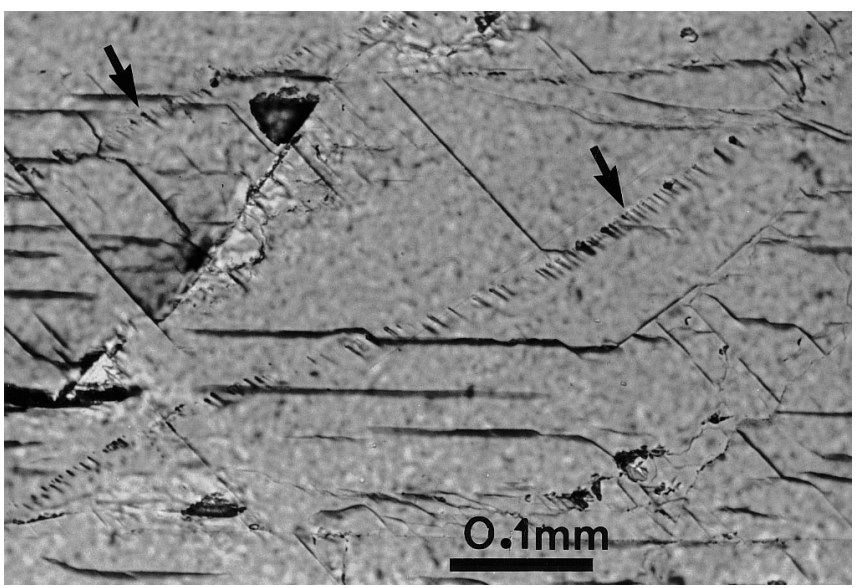

Fig. 9 Trains of tubular fluid inclusions (arrows) in a single crystal of hornblende, revealing the locations of healed microfractures (pegmatitic dike, sample KEH402A; see also Fig. 4D)

Near the northeastern margin of the complex, the gabbros were thoroughly recrystallized during a contact metamorphic event caused by emplacement of the Hutchinson Glacier syenite intrusions (Fig. 3). Within a few hundred meters of the contacts the gabbros contain secondary hornblendes with $\delta \mathrm{D}$ values between -125 and $-123 \%$ (Nevle et al. 1994). These 
hornblendes have Ar-Ar ages of $42 \mathrm{Ma}$ (Nevle et al. 1994). and are therefore younger than the $\sim 50 \mathrm{Ma}$ hornblendes of Stand and Deliver Nunatak. The $\delta \mathrm{D}$ values in the syenite aureoles thus reflect alteration by meteoric waters that were younger and isotopically heavier than those which left their signatures at Stand and Deliver Nunatak. This younger hydrothermal system may also account for the $\delta \mathrm{D}$ value of $-131 \%$ reported by Fehlhaber and Bird (1991) for an actinolite in altered gabbro several kilometers from the syenite contact.

Several samples have also been analyzed from Contact Nunatak, located near the northwestern corner of the complex (Fig. 3; Brandriss 1993). A sample of actinolite lining a vug in gabbro had a $\delta \mathrm{D}$ value of $-143 \%$ and a $\delta^{18} \mathrm{O}$ value of $+4.0 \%$. Phlogopite in a pegmatitic pod from a xenolith in a nearby outcrop had a $\delta \mathrm{D}$ value of $-128 \%$. These $\delta \mathrm{D}$ values are higher than those of similar minerals at Stand and Deliver Nunatak, and might record the effects of a younger meteoric-hydrothermal system associated with emplacement of syenites a few hundred meters east of the sample locality (Fig. 3). These syenites intruded and brecciated the layered gabbros over an exposed area of tens of square kilometers (Abbott and Deer 1972).

In summary, most hydrous minerals from the northern parts of the Kap Edvard Holm Complex have $\delta \mathrm{D}$ values that are higher than those of minerals at Stand and Deliver Nunatak. Many of these higher $\delta \mathrm{D}$ values, and perhaps all of them, can be attributed to alteration of the gabbros by meteoric-hydrothermal systems associated with younger syenitic intrusions. It is possible that the similarly high $\delta \mathrm{D}$ values of minerals from the epidote-actinolite vein at Stand and Deliver Nunatak (sample KEH259E) might reflect very localized alteration along a vein system associated with these younger hydrothermal events.

\section{Early Tertiary meteoric water compositions}

Rocks from Stand and Deliver Nunatak interacted with Eocene meteoric waters that were isotopically lighter than any early Tertiary meteoric waters previously inferred for the North Atlantic Tertiary Igneous Province. The hydrothermal system was supplied with meteoric water that had a $\delta \mathrm{D}$ value of $-110 \pm 10 \%$; $\delta \mathrm{D}$ values of -100 to $-85 \%$ have been calculated for meteoric waters in early Tertiary hydrothermal systems associated with the Skaergaard and Lilloise intrusions in eastern Greenland, and the Skye intrusive center in northwestern Scotland (Forester and Taylor 1977; Sheppard et al. 1977; Taylor and Forester 1979). In all of these studies, the $\delta \mathrm{D}$ values of meteoric waters were calculated from the hydrogen isotope compositions of secondary minerals in altered rocks. When the $\delta \mathrm{D}$ values of minerals are compared directly (Fig. 10), the differences between Stand and Deliver Nunatak and

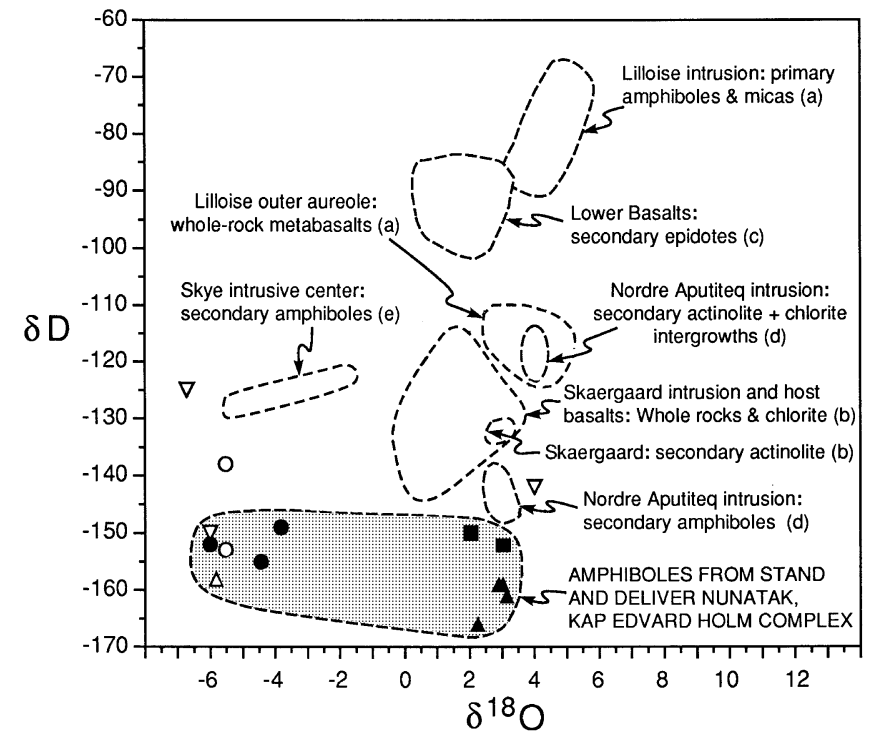

\begin{tabular}{l}
\hline MINERALS FROM STAND AND DELIVER NUNATAK \\
$\triangle$ Secondary actinolite \\
O Secondary amphibole + chlorite \\
$\Delta$ Primary intergranular hornblende, postcumulus peridotite and gabbro \\
- Primary hornblende, postcumulus pegmatitic dikes \\
- Primary hornblende, pegmatitic pods enclosed in xenoliths \\
MINERALS FROM OTHER PARTS OF THE KAP EDVARD HOLM COMPLEX \\
$\nabla$ Secondary amphibole
\end{tabular}

Fig. 10 Hydrogen and oxygen isotope compositions of rocks and minerals from early Tertiary lavas and intrusions in East Greenland and Scotland. Data for Stand and Deliver Nunatak are from this study. Data for other samples from the Kap Edvard Holm Complex are from Fehlhaber and Bird (1991), Brandriss (1993), and Nevle et al. (1994). Sources of other data are: (a) Sheppard et al. 1977, (b) Taylor and Forester 1979, (c) D.K. Bird, unpublished data, (d) Rose 1989, (e) Forester and Taylor (1977)

the other intrusions (up to $60 \%$ for amphibole) are seen to be even greater than the differences in calculated meteoric water compositions. Thus, if the same assumptions are used to calculate isotopic fractionations between minerals and water in all of the different intrusions, then the contrast between calculated meteoric water compositions is even greater than that inferred from published estimates.

The anomalously low $\delta \mathrm{D}$ values of the Eocene meteoric waters at Stand and Deliver Nunatak might be related to the development of a regional topographic anomaly at around the time that the gabbros were emplaced and the hydrothermal system was active. Brooks (1979) and Gleadow and Brooks (1979) postulated that the Kangerdlugssuaq area was uplifted about 50 million years ago, forming a structural dome several hundred kilometers in diameter with a maximum uplift of about $6.5 \mathrm{~km}$ at the center. Their postulated age for the doming event is similar to the ${ }^{40} \mathrm{Ar} /{ }^{39} \mathrm{Ar}$ ages of 49-50 Ma measured for low- $\delta \mathrm{D}$ hornblendes from Stand and Deliver Nunatak (Nevle et al. 1994). The 
Kap Edvard Holm complex is located on the flank of the postulated dome, with a cumulative uplift of about three or four kilometers projected for Stand and Deliver Nunatak (Brooks 1979, 1985). The isotopic compositions of meteoric waters are known to vary dramatically with altitude, with $\delta \mathrm{D}$ values typically decreasing by about $1.5-4.0 \%$ per $100 \mathrm{~m}$ increase in elevation (Dansgaard 1964; Yurtsever and Gat 1981). If the recharge area of the hydrothermal system were uplifted by several kilometers, then the elevation change could easily account for the low $\delta \mathrm{D}$ values of meteoric-hydrothermal waters at Stand and Deliver Nunatak (Nevle et al. 1994). Isotopic variations in this exhumed pluton thus appear to provide information on localized climatic variations during the early Tertiary tectonic evolution of the North Atlantic ocean basin.

Acknowledgements Financial support for this work was provided by the Geological Society of America research grant program, the Richard H. Jahns Memorial Fund, the Chevron Foundation, the Shell Fund, the Dean and Dorothea McGee Foundation, and the National Science Foundation (grants NSF-EAR-8803754, NSF-EAR-9004007, and NSF-EAR-9220431, all to D.K. Bird, and NSF-EAR-9205314 to J.R. O'Niel). Logistical support in the field was provided by Platinova Resources Inc, Dihedral Exploration, and Mr. Hreinn Skagfjord. Peter Schiffman and Sarah Roeske performed the electron microprobe analyses at the University of California, Davis. Greg Arehart and Torsten Vennemann provided much valuable help in the stable isotope laboratory. Prior to submission, this manuscript benefitted from careful reviews by Ronadh Cox, Konrad Krauskopf, Gail Mahood and Jonathan Stebbins. Bob Criss and an anonymous reviewer provided comprehensive and extremely useful reviews which resulted in substantial improvements to the final version.

\section{References}

Abbott D, Deer WA (1972) Geological investigations in East Greenland, Part X: the gabbro cumulates of the Kap Edvard Holm Lower Layered Series. Medd Groenl 190(6)

Bernstein S, Rosing MT, Brooks CK, Bird DK (1992) An ocean-ridge type magma chamber at a passive volcanic, continental margin: the Kap Edvard Holm layered gabbro complex, East Greenland. Geol Mag 129:437-456

Bird DK, Manning CE, Rose NM (1988a) Mineralogic and isotopic constraints on the regional hydrology of the Skaergaard magma-hydrothermal system, East Greenland. Geol Soc Am Abstr Prog 20: A344.

Bird DK, Manning CE, Rose NM (1988b) Hydrothermal alteration of Tertiary layered gabbros, East Greenland. Am J Sci 288: 405-457.

Bott MHP (1987) The continental margin of central East Greenland in relation to North Atlantic plate tectonic evolution. J Geol Soc London 144:561-568

Bottinga Y, Javoy M (1975) Oxygen isotope partitioning among the minerals in igneous and metamorphic rocks. Rev Geophys Space Phys 13:401-418

Brandriss, ME (1993) Assimilation of metabasalt xenoliths and postcumulus metasomatism of gabbros in the Kap Edvard Holm Complex, East Greenland. PhD dissertation, Stanford University

Brandriss ME, Bird DK, O'Neil JR (1992) Dependence of hydrotheral alteration on rock texture and microporosity in mafic crystalline rocks. In: Kharaka YK, Maest AS (eds) Proc 7th international symposium on water-rock interaction, vol 2: moderate and high temperature environments. AA Balkema, Rotterdam, pp 1477-1480

Brooks CK (1979) Geomorphological observations at Kangerdlugssuaq, East Greenland. Medd Groenl, Geoscience 1

Brooks CK (1985) Vertical crustal movements in the Tertiary of central East Greenland: a continental margin at a hot-spot. Z Geomorphol, Supplementband 54:101-117

Clayton RN, Mayeda TK (1963) The use of bromine pentafluoride in the extraction of oxygen from oxides and silicates for isotopic analysis. Geochim Cosmochim Acta 27:43-52

Cole DR, Ohmoto H (1986) Kinetics of isotope exchange at elevated temperatures and pressures. In: Valley JW, Taylor HP Jr, O'Neil JR (eds) Stable isotopes in high temperature geological processes (Reviews in Mineralogy vol. 16) Mineralogical Society of America, Washington DC, pp 41-90

Cole DR, Ohmoto H, Lasaga AC (1983) Isotopic exchange in mineral-fluid systems. I. Theoretical evaluation of oxygen isotopic exchange accompanying surface reactions and diffusion. Geochim Cosmochim Acta 47:1681-1693

Craig H (1961) Isotopic variations in meteoric waters. Science 133: $1702-1703$

Crank J (1975) The mathematics of diffusion. Clarendon Press, Oxford

Criss RE, Taylor HP Jr (1986) Meteoric-hydrothermal systems. In: Valley JW, Taylor HP Jr, O'Neil JR (eds) Stable isotopes in high temperature geological processes (Reviews in Mineralogy vol. 16) Mineralogical Society of America, Washington DC, pp 373-424

Dansgaard W (1964) Stable isotopes in precipitation. Tellus 16:436-468

Deer WA, Abbott D (1965) Clinopyroxenes of the gabbro cumulates of the Kap Edvard Holm complex, East Greenland. Mineral Mag, Tilley volume: $177-193$

Deer WA, Kempe DRC, Jones GC (1984) Syenites and associated intrusions of the Kap Edvard Holm region of Kangerdlugssuaq, East Greenland. Medd Groenl, Geoscience 12

Elsdon R (1969) The structure and intrusive mechanism of the Kap Edvard Holm layered gabbro complex, East Greenland. Geol Mag 106:46-56

Elsdon R (1972) Iron-titanium oxide minerals in the Upper Layered Series, Kap Edvard Holm Complex, East Greenland. Mineral Mag 38:946-956

Farver JR, Giletti BJ (1985) Oxygen diffusion in amphiboles. Geochim Cosmochim Acta 49:1403-1411

Farver JR, Giletti BJ (1989) Patterns and processes of oxygen isotope exchange in a fossil meteoric hydrothermal system, Cuillins gabbro complex, Isle of Skye, Scotland. Contrib Mineral Petrol 102:24-33

Fehlhaber K, Bird DK (1991) Oxygen-isotope exchange and mineral alteration in gabbros of the Lower Layered Series, Kap Edvard Holm Complex, East Greenland. Geology 19:819-822

Forester R, Taylor HP Jr $(1977){ }^{18} \mathrm{O} /{ }^{16} \mathrm{O}, \mathrm{D} / \mathrm{H}$, and ${ }^{13} \mathrm{C} /{ }^{12} \mathrm{C}$ studies of the Tertiary igneous complex of Skye, Scotland. Am J Sci 277: $137-177$

Forester RW, Taylor HP Jr (1976) ${ }^{18} \mathrm{O}$-depleted rocks from the Tertiary complex of the Isle of Mull, Scotland. Earth Planet Sci Lett 32:11-17

Fram MS (1994) Petrogenesis of the early Tertiary flood basalts of the East Greenland continental margin. PhD dissertation, Columbia University

Giletti BJ (1985) The nature of oxygen transport within minerals in the presence of hydrothermal water and the role of diffusion. Chem Geol 53: 197-206

Giletti BJ, Semet MP, Yund RA (1978) Studies in diffusion-III. Oxygen in feldspars: an ion microprobe determination. Geoch in Cosmochim Acta 42:45-57

Gill RCO, Nielsen TFD, Brooks CK, Ingram GA (1988) Tertiary volcanism in the Kangerdlugssuaq region, E Greenland: trace-element geochemistry of the Lower Basalts and tholeiitic 
dyke swarms. In: Morton AC, Parsons LM (eds) Early Tertiary volcanism and the opening of the NE Atlantic. Geol Soc London Spec Pub 39:161-179

Gleadow AJW, Brooks CK (1979) Fission track dating, thermal histories and tectonics of igneous intrusions in East Greenland. Contrib Mineral Petrol 71:45-60

Graham CM, Harmon RS, Sheppard SMF (1984) Experimental hydrogen isotope studies: hydrogen isotope exchange between amphibole and water. Am Mineral 69:128-138

Gregory RT, Criss RE, Taylor HP Jr (1989) Oxygen isotope exchange kinetics of mineral pairs in closed and open systems: applications to problems of hydrothermal alteration of igneous rocks and Precambrian iron formations. Chem Geol 75:1-42

Holm PM (1988) Nd, $\mathrm{Sr}$ and $\mathrm{Pb}$ isotope geochemistry of the Lower Lavas, E Greenland Tertiary Igneous Province. In: Morton AC, Parsons LM (eds) Early Tertiary volcanism and the opening of the NE Atlantic. Geol Soc London Spec Pub 39:181-195

Kyser TK (1986) Stable isotope variations in the mantle. In: Valley JW, Taylor HP Jr, O'Neil JR (eds) Stable isotopes in high temperature geological processes (Reviews in Mineralogy vol. 16) Mineralogical Society of America, Washington DC, pp 141-164

Manning CE, Bird DK (1991) Porosity evolution and fluid flow in the basalts of the Skaergaard magma-hydrothermal system, East Greenland. Am J Sci 291:201-257

Manning CE, Bird DK (1995) Porosity, permeability, and basalt metamorphism. In: Schiffman P, Day HW (eds) Low-grade metamorphism of mafic rocks. Geol Soc Am Spec Pap 296: 123-140.

Manning CE, Ingebritsen SE, Bird DK (1993) Missing mineral zones in contact metamorphosed basalts. Am J Sci 293:894-938

Matthews A, Goldsmith JR, Clayton RN (1983) Oxygen isotope fractionations involving pyroxenes: the calibration of mineral-pair geothermometers. Geochim Cosmochim Acta 47:631-644

Mussett AE, Dagley P, Skelhorn RR (1988) Time and duration of activity in the British Tertiary Volcanic Province. In: Morton AC, Parsons LM (eds) Early Tertiary volcanism and the opening of the NE Atlantic. Geol Soc London Spec Pub 39:337-348

Nevle RJ, Brandriss ME, Bird DK, McWilliams MO, O'Neil JR (1994) Tertiary plutons monitor climate change in East Greenland. Geology 22:775-778

Nielsen TFD, Soper NJ, Brooks CK, Faller AM, Higgins AC, Matthews, DW (1981) The pre-basaltic sediments and the Lower Basalts at Kangerdlugssuaq, East Greenland: their stratigraphy, lithology, palaeomagnetism and petrology. Medd Groenl, Geoscience 6
Noble RH, Macintyre RM, Brown PE (1988) Age constraints on Atlant!ic evolution: timing of magmatic activity along the E Greenland continental margin. In: Morton AC, Parsons LM (eds) Early Tertiary volcanism and the opening of the NE Atlantic. Geol Soc London Spec Pub 39:201-214

O'Neil JR, Taylor HP Jr (1967) The oxygen isotope and cation exchange chemistry of feldspars. Am Mineral 52:1414-1437

Rose NM (1989) Geochemistry of hydrothermal metasomatism in basaltic systems. PhD dissertation, Stanford University

Sheppard SMF, Brown PE, Chambers AD (1977) The Lilloise intrusion, East Greenland: evidence for the efflux of magmatic water into the contact metamorphic aureole. Contrib Mineral Petrol 63:129-147

Snyder RL, Bish DL (1989) Quantitative analysis. In: Bish DL, Post JE (eds) Modern powder diffraction (Reviews in Mineralogy vol. 20) Mineralogical Society of America, Washington DC, pp $101-144$

Soper NJ, Downie C, Higgins AC, Costa LI (1976) Biostratigraphic ages of the Tertiary basalts on the East Greenland continental margin and their relationship to plate separation in the Northeast Atlantic. Earth Planet Sci Lett 32:149-157

Suzuoki T, Epstein S (1976) Hydrogen isotope fractionations between $\mathrm{OH}$-bearing minerals and water. Geochim Cosmochim Acta 40:1229-1240

Taylor HP Jr (1974) The application of oxygen and hydrogen isotope studies to problems of hydrothermal alteration and ore deposition. Econ Geol 69:843-883

Taylor HP Jr (1977) Water/rock interactions and the origin of $\mathrm{H}_{2} \mathrm{O}$ in granitic batholiths. J Geol Soc London 133:509-558

Taylor HP Jr, Forester RW (1971) Low $-{ }^{18}$ O igneous rocks from the intrusive complexes of Skye, Mull, and Ardnamurchan, Western Scotland. J Petrol 12:465-497.

Taylor HP Jr, Forester RW (1979) An oxygen and hydrogen isotope study of the Skaergaard intrusion and its country rocks: a description of a $55 \mathrm{~m} . \mathrm{y}$. old fossil hydrothermal system. J Petrol 20:355-419

Vennemann TW, O'Neil JR (1993) A simple and inexpensive method of hydrogen isotope and water analyses of minerals and rocks based on zinc reagent. Chem Geol 103:227-234

Wilson AD (1955) Determination of ferrous iron in rocks and minerals. Bull Geol Surv GB 9:56-58

Yurtsever Y, Gat JR (1981) Atmospheric waters. In: Gat JR, Gonfiantini $\mathrm{R}$ (eds) Stable isotope hydrology, deuterium and oxygen-18 in the water cycle. International Atomic Energy Agency Technical Reports Series 210, Vienna, pp 103-142 